\title{
1-0-Octadecyl-2-0-methyl-glycerophosphocholine Inhibits the Transduction of Growth Signals via the MAPK Cascade in Cultured MCF-7 Cells
}

\author{
Xi Zhou, ${ }^{\star}$ Xiaoli Lu, ${ }^{*}$ Christina Richard, ${ }^{\star}$ Wei Xiong, ${ }^{*}$ David W. Litchfield, ${ }^{\star \ddagger}$ Robert Bittman, ${ }^{\S}$ and Gilbert Arthur \\ *Department of Biochemistry and Molecular Biology, Faculty of Medicine, University of Manitoba, Winnipeg, Manitoba, Canada R3E \\ OW3; ${ }^{\ddagger}$ Manitoba Institute of Cell Biology, Winnipeg, Manitoba, Canada R3E 0V9; and ${ }^{\S}$ Department of Chemistry and Biochemistry, \\ Queens College of the City University of New York, Flushing, New York 11367
}

\begin{abstract}
1-O-Octadecyl-2-O-methyl-glycerophosphocholine (ET18$\mathrm{OCH}_{3}$ ) is an ether lipid with selective antiproliferative properties whose mechanism of action is still unresolved. We hypothesized that since $\mathrm{ET} 18-\mathrm{OCH}_{3}$ affects a wide variety of cells, its mechanism of action was likely to involve the inhibition of a common widely used pathway for transducing growth signals such as the mitogen-activated protein kinase (MAPK) cascade. To test this, we established conditions whereby quiescent MCF-7 cells took up ET18- $\mathrm{OCH}_{3}$ in sufficient quantities that inhibited cell proliferation subsequent to the addition of growth medium and examined the activation of components of the MAPK cascade under these conditions. ET18- $\mathrm{OCH}_{3}$ inhibited the sustained phosphorylation of MAPK resulting in a decrease in the magnitude and duration of activation of MAPK in cells stimulated with serum or EGF. ET18- $\mathrm{OCH}_{3}$ had no effect on the binding of EGF to its receptors, their activation, or $\mathrm{p} 21^{\text {ras }}$ activation. However, an interference in the association of Raf-1 with membranes and a resultant decrease in Raf-1 kinase activity in membranes of ET18- $\mathrm{OCH}_{3}$-treated cells was observed. ET18- $\mathrm{OCH}_{3}$ had no direct effect on MAPK or Raf-1 kinase activity. A direct correlation between ET18- $\mathrm{OCH}_{3}$ accumulation, inhibition of cell proliferation, Raf association with the membrane, and MAPK activation was also established. These results suggest that inhibition of the MAPK cascade by ET18- $\mathrm{OCH}_{3}$ as a result of its effect on Raf-1 activation may be an important mechanism by which ET18- $\mathrm{OCH}_{3}$ inhibits cell proliferation. (J. Clin. Invest. 1996. 98:934-944.) Key words: phospholipid ethers - antineoplastic agents • cell division • signal transduction • protein kinases
\end{abstract}

\section{Introduction}

1-O-Octadecyl-2- $O$-methyl-glycerophosphocholine (ET18$\left.\mathrm{OCH}_{3}\right),{ }^{1}$ also known as edelfosine, is the prototype of a class of antitumor ether lipids, the alkyllysophospholipids (ALPs), with a wide range of antitumor activity that are undergoing clinical trials (1-3). Two characteristics of the antiproliferative effect

Address correspondence to Gilbert Arthur, Department of Biochemistry and Molecular Biology, University of Manitoba, 770 Bannatyne Avenue, Winnipeg, Manitoba, Canada, R3E 0W3. Phone: 204-7893758; 204-783-0864; E-mail: arthur@bldghsc.lan1.umanitoba.ca

Received for publication 17 January 1996 and accepted in revised form 6 June 1996.

J. Clin. Invest.

(C) The American Society for Clinical Investigation, Inc.

0021-9738/96/08/0937/08 \$2.00

Volume 98, Number 4, August 1996, 937-944 exhibited by these compounds have generated considerable interest. Firstly, inhibition of cell proliferation appears to be achieved without any interaction with cellular DNA and secondly, these antiproliferative effects are cell selective (1). The mechanism of inhibition of cell proliferation by ALPs is still unresolved and although they affect a large number of cellular events including nutrient transport, TGF- $\alpha$ secretion, estradiol uptake, transferrin binding, and intracellular-free $\mathrm{Ca}^{2+}$ levels (reviewed in 1-3), the role of these perturbations in inhibiting cell growth has yet to be established. ET18- $\mathrm{OCH}_{3}$ also perturbs lipid metabolism but recent studies have suggested that this is unlikely to be the underlying cause for its antiproliferative effect (4-7).

There is a growing recognition that ALPs may inhibit cell growth by interfering in signal transduction processes. Inhibition of protein kinase $\mathrm{C}$ (PKC) has been proposed as the mechanism by which ET18- $\mathrm{OCH}_{3}$ and related compounds inhibit cell proliferation (8), but this is contentious. ET18- $\mathrm{OCH}_{3}$ may inhibit (9) or activate (10) PKC activity in in vitro assays depending on the mode of presentation of the ALP in the assay, but a number of studies have revealed no correlation between inhibition of cell growth and inhibition of PKC activity $(2,11,12)$. Decreased inositol 1,4,5-trisphosphate $\left(\operatorname{Ins} P_{3}\right)$ production in response to incubation of cells with antitumor ether lipids has been reported (13) and could be due to inhibition of phosphatidylinositol-specific phospholipase C (PI-PLC) (14). Observations that ET18-OCH${ }_{3}$ inhibited PI-3-OH-kinase (PI$3 \mathrm{~K})$ activity in purified preparations and cell lysates and reduced the production of 3-phosphorylated inositol lipids after PDGF stimulation of NIH 3 T3 cells (15) led to the suggestion that the mechanism by which ALPs inhibit cell proliferation may involve the inhibition of PI-3K. PI-3K activation may not be sufficient to initiate cell proliferation and its contribution to proliferation is yet to be fully established (16). The wide range of cancer cells whose growth is inhibited by ET18- $\mathrm{OCH}_{3}$ suggests that a common mechanism of action, if one existed, was likely to involve perturbation of a widely used signal transduction mechanism that initiates proliferation. One such pathway is the Ras-dependent activation of the mitogen-activated protein kinase (MAPK) cascade (Ras/Raf-1/MEK/ERK) which transduces signals from receptor tyrosine kinases, oncogenic tyrosine kinases, and G-protein-coupled receptors $(17,18)$.

1. Abbreviations used in this paper: AEBSF, aminoethylbenzenesulfonyl fluoride; ALP, alkyllysophospholipid; DME/FBS (or/BSA), DME supplemented with $10 \%$ FBS (or with $0.5 \mathrm{mg} / \mathrm{ml} \mathrm{BSA}$ ); EGFr, EGF receptor; ERK, extracellular signal-regulated kinase; ET18$\mathrm{OCH}_{3}, 1$ - $O$-octadecyl-2- $O$-methyl-glycerophosphocholine; MAPK, mitogen-activated protein kinase; MBP, myelin basic protein; MEK, MAPK/extracellular signal-regulated kinase; PI-3K, phosphatidylinositol-3-OH kinase; PI-PLC, PI-specific phospholipase C; PKA, protein kinase $\mathrm{A}$; $\mathrm{PKC}$, protein kinase $\mathrm{C}$; TPA, 12- $O$-tetradecanoylphorbol-13-acetate. 
We, therefore, investigated the effects of $\mathrm{ET} 18-\mathrm{OCH}_{3}$ on signaling via the MAPK cascade in the human breast adenocarcinoma cell line, MCF-7, which is very sensitive to the antiproliferative effects of ET18-OCH $\mathrm{OCH}_{3}$ (19). Here we show that ET18- $\mathrm{OCH}_{3}$ inhibits the transduction of growth signals via the MAPK cascade in MCF-7 cells by perturbing the association of Raf- 1 with the membrane. This truncates Raf- 1 kinase activity and prevents the sustained activation of the MAPK cascade.

\section{Methods}

Materials. ET18- $\mathrm{OCH}_{3}$ was obtained from Medmark (Gruenwald, Germany). EGF, myelin basic protein (MBP), all protease inhibitors, calmidazolium and $\mathrm{Na}_{3} \mathrm{VO}_{4}$, were purchased from Sigma Chemical Co. (St. Louis, MO). Coomassie protein assay reagent was a product of Pierce (Rockford, IL). FBS (Cellect Gold), $\left[{ }^{3} \mathrm{H}\right]$ thymidine, $2 \mathrm{Ci} /$ $\mathrm{mmol}\left[\gamma^{32} \mathrm{P}\right] \mathrm{ATP}$, and $\left.{ }^{32} \mathrm{P}\right]$ orthophosphate were obtained from ICN Pharmaceuticals (Montreal, Quebec). Cell culture medium and subculturing reagents were purchased from Gibco BRL (Burlington, Ontario). PEI cellulose TLC plates were purchased from E. Merck (Darmstedt, Germany). Anti-ERK1 (C-16), -ERK2 (C-14), -Ras (259), and -Raf-1 (C-12) antibodies and MEK-1 (FL) were obtained from Santa Cruz Biotechnology, Inc. (Santa Cruz, CA). Sheep polyclonal anti-EGF receptor $\mathrm{Ab}$ and mouse antiphosphotyrosine $\mathrm{mAb}$ were procured from Upstate Biotechnology Inc. (Lake Placid, NY). Anti-Raf-1 antiserum (SP63) was generously provided by Dr. U. Rapp (National Cancer Institute, NIH). cAMP $\left[{ }^{3} \mathrm{H}\right]$ assay kit was from Amersham Canada (Oakville, Ontario). PKI and Kemptide were purchased from Bachem (Torrance, CA).

Cell culture. MCF-7 (human breast adenocarcinoma) cells from frozen stocks originally obtained from American Type Culture Collection (Rockville, MD) were cultured in DME/FBS (19). Quiescent cells were obtained by seeding cells in tissue culture dishes overnight in DME/FBS followed by incubation in DME/BSA for 4-6 d. The cells were considered quiescent when the $24 \mathrm{~h}$ increase in cell number of parallel cultures was $15 \%$ or less.

ET18-OCH $\mathrm{OH}_{3}$ preincubation and cell activation. Working solutions of DME/BSA supplemented with ET18- $\mathrm{OCH}_{3}$ were prepared fresh. Quiescent cells were incubated with or without ET18-OCH $\mathrm{O}_{3}(10 \mu \mathrm{g} /$ $\mathrm{ml}$ ) in fresh DME/BSA. At the end of the incubation, the medium was aspirated, the cells were washed and stimulated with DME/FBS or EGF $(10 \mathrm{ng} / \mathrm{ml})$ for selected times. The cells were then washed and scraped into the appropriate buffer and sonicated. Cytosol was obtained by centrifugation at $200,000 \mathrm{~g}$ for $30 \mathrm{~min}$ and frozen at $-70^{\circ} \mathrm{C}$ until required. The protein content of fractions was determined by the Coomassie protein assay. The basic buffer for most of the studies, buffer A, consisted of $20 \mathrm{mM}$ Tris- $\mathrm{HCl}$ ( $\mathrm{pH} 7.4$ ), $150 \mathrm{mM} \mathrm{NaCl}, 2 \mathrm{mM}$ EGTA, $100 \mathrm{mM} \beta$-glycerophosphate, $1 \mathrm{mM} \mathrm{Na}_{3} \mathrm{VO}_{4}$, aprotinin, leupeptin $(10 \mu \mathrm{g} / \mathrm{ml}$ each), $0.2 \mathrm{mM}$ aminoethylbenzenesulfonyl fluoride (AEBSF), $0.1 \mathrm{mM}$ PMSF, and $0.2 \mathrm{mM}$ benzamidine.

Protein kinase assays. Cells were scraped into buffer B (buffer A without $\mathrm{NaCl}$ plus $1 \mathrm{mM}$ DTT), and disrupted by ultrasonication. Cell cytosol was obtained by centrifugation as described above. MAPK activity was measured as the phosphorylation of MBP in vitro (20) in the presence of $2 \mu \mathrm{M}$ PKI peptide, $10 \mu \mathrm{M}$ calmidazolium and $1 \mu \mathrm{M}$ PKC inhibitor peptide or by the in-gel assay (21) after electrophoresis on $10 \%$ SDS gels. PKA activity was measured with Kemptide as substrate (22) and was taken as the difference in phosphorylation of the peptide in the absence and presence of PKI $(2 \mu \mathrm{M})$.

Phosphorylation of MAPK. Quiescent cells were washed with Krebs buffer and incubated with phosphate-free DME/BSA containing $300 \mu \mathrm{Ci} / \mathrm{ml}\left[{ }^{32} \mathrm{P}\right]$ orthophosphate for $3 \mathrm{~h}$ followed by washing and incubation with or without ET18- $\mathrm{OCH}_{3}(10 \mu \mathrm{g} / \mathrm{ml})$ for $3 \mathrm{~h}$. At the end of the incubation the cells were washed and incubated with DME/ BSA and stimulated for selected periods with EGF. The cells were then quickly washed three times with ice-cold Krebs buffer and scraped into buffer C (buffer A $+1 \%$ [wt/vol] Triton X-100, $0.5 \%$ [wt/vol] NP-40), vortexed immediately, and centrifuged at 200,000 $\mathrm{g}$ for $30 \mathrm{~min}$. Cell cytosol was precleared followed by immunoprecipitation of $\mathrm{p} 42^{\mathrm{mapk}}$ and $\mathrm{p} 44^{\mathrm{mapk}}$ with agarose-conjugated polyclonal Abs to ERK1 (C-16) and ERK2 (C-14). Pellets were washed (eight times) with buffer $\mathrm{C}$ followed by boiling in SDS sample buffer. The proteins were separated on $10 \%$ SDS gels and phosphorylated bands were visualized by autoradiography.

EGF receptor phosphorylation. After the appropriate treatment and stimulation of cells with EGF, the cells were washed twice and lysed in $50 \mathrm{mM}$ Hepes (pH 7.5), $150 \mathrm{mM} \mathrm{NaCl}, 1 \%$ (wt/vol) Triton X-100, $1.5 \mathrm{mM} \mathrm{MgCl}_{2}, 1 \mathrm{mM}$ EGTA, protease inhibitors (aprotinin, leupeptin, benzamidine, AEBSF), $0.5 \mathrm{mM} \mathrm{Na}_{3} \mathrm{VO}_{4}$ and $100 \mathrm{mM} \beta$-glycerophosphate. The extracts were sonicated and centrifuged at 200,000 $g$ for $30 \mathrm{~min}$. The supernatant was used for immunoprecipitation with sheep polyclonal anti-EGFr Ab followed by Western blot analysis with the same $\mathrm{Ab}$ or mouse antiphosphotyrosine $\mathrm{mAb}$.

p21 ras activation. Ras was immunoprecipitated with a rat anti$\mathrm{v}-\mathrm{H}$-Ras $\mathrm{mAb}(259)$ from $\left[{ }^{32} \mathrm{P}\right]$ orthophosphate $(300 \mu \mathrm{Ci} / \mathrm{ml}, 4 \mathrm{~h})-$ labeled quiescent cells stimulated for selected periods with EGF. The GTP/(GTP + GDP) content was determined as previously described (23).

Translocation of Raf-1. This was performed as described by Wartmann and Davis (24). Quiescent cells treated with or without ET18- $\mathrm{OCH}_{3}$ were stimulated with EGF or serum. The cytosolic fraction and solubilized membrane fraction were prepared (24) and subjected to Western blot analysis with anti-Raf-1 (C-12) Ab after electrophoresis on $10 \%$ SDS-PAGE.

Raf-1 kinase assays. Membranes were obtained from control and ET18-OCH${ }_{3}$-treated cells, solubilized (24), and were precleared. Immunoprecipitation was achieved with anti-Raf-1 antiserum (SP63) (25). Raf-1 kinase activity was assayed (25) by using $10 \mu \mathrm{g}$ of histone $\mathrm{H} 1$ or $2.5 \mu \mathrm{g}$ of MEK (FL) as substrates. Radiolabeled histone H1 or MEK was separated on $12 \%$ SDS gels and visualized by autoradiography.

$\left[{ }^{3} \mathrm{H}\right]$ Thymidine incorporation in cells. Quiescent cells in 6-well plates were preincubated with or without ET18-OCH $(10 \mu \mathrm{g} / \mathrm{ml})$ for selected periods. After washing, the cells were incubated with DME/ BSA or DME/FBS for $20 \mathrm{~h}$ followed by the addition of $\left[{ }^{3} \mathrm{H}\right]$ thymidine $0.5 \mu \mathrm{Ci} /$ well for an additional $4 \mathrm{~h}$. Radioactivity in TCA precipitable material was determined (26).

Determination of cellular cAMP levels. cAMP levels were measured with a kit from Amersham Corp. using the protocol enclosed with the kit without any modifications.

Flow cytometry. Cells were processed for flow cytometry analysis as previously described (27). Data were collected and analyzed with a cell sorter EPICS 753; Coulter Electronics Inc., Hialeah, FL and the PARA 1 analysis software (Coulter Electronics Inc.).

Quantitation. Quantitation of immunoblots and autoradiographs were obtained by densitometric analysis with a high resolution color scanner model PDI 325oe (Protein + DNA Imageware Systems, Huntington Station, NY) using the ImageMaster scanning program (Pharmacia LKB Biotechnology Inc., Piscataway, NJ).

\section{Results}

ET18-OCH $\mathrm{H}_{3}$ inhibits the serum-induced cell proliferation and $\left[{ }^{3} H\right]$ thymidine incorporation. The approach adopted for this study was to investigate the effect of $\mathrm{ET} 18-\mathrm{OCH}_{3}$ on the proliferation of quiescent cells. To correlate any observed cellular perturbations with the inhibition of cell growth, incubation conditions were established whereby quiescent MCF-7 cells accumulated sufficient ET18-OCH 3 to inhibit cell proliferation after the readdition of DME/FBS without loss of cell viability. The addition of DME/FBS to serum-deprived MCF-7 cells stimulated proliferation, while continued deprivation of serum did not (Fig. $1 \mathrm{~A}$ ). Preincubation of the cells with ET18-OCH $\mathrm{OCH}_{3}(10$ $\mu \mathrm{g} / \mathrm{ml}$ ) for $1 \mathrm{~h}$ and subsequent incubation with DME/FBS de- 

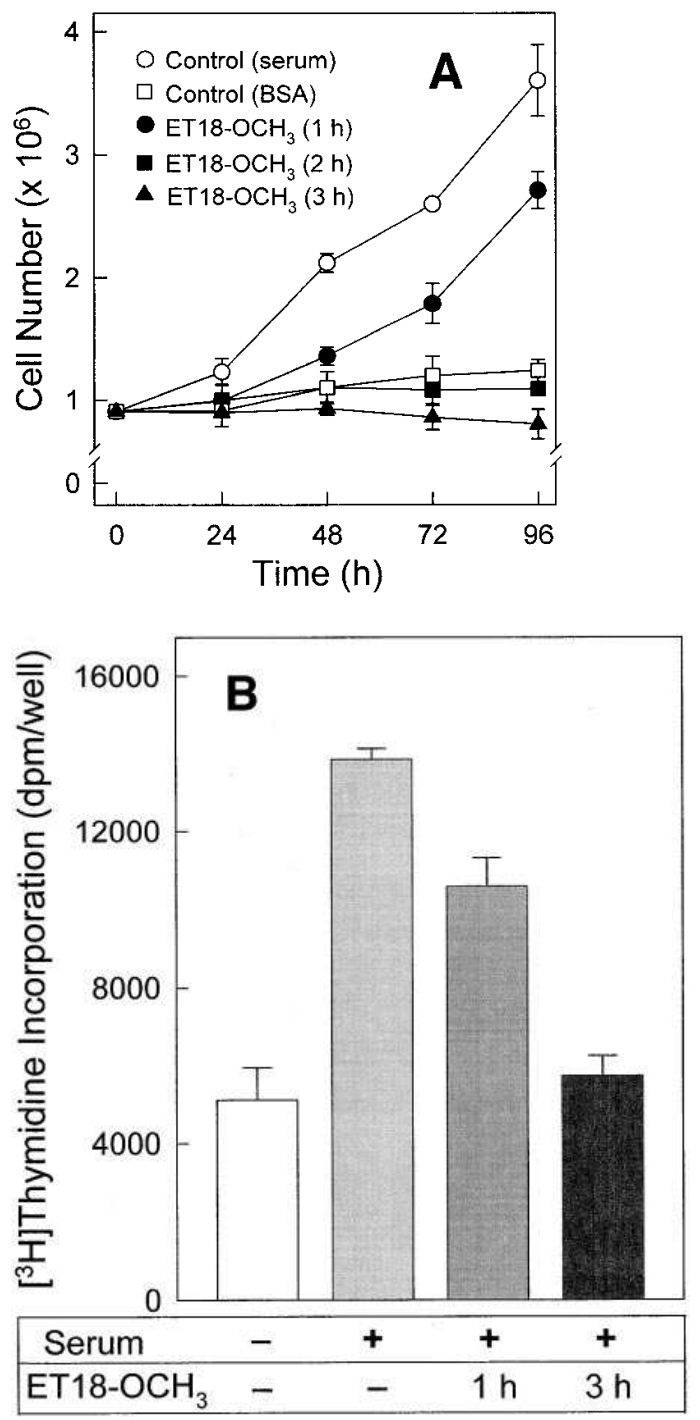

Figure 1. Preincubation of quiescent MCF-7 cells with ET18-OCH inhibits cell proliferation and thymidine incorporation. $(A)$ Quiescent MCF-7 cells were incubated with $10 \mu \mathrm{g} / \mathrm{ml}$ ET18-OCH ${ }_{3}$ for $1 \mathrm{~h}(\bullet), 2 \mathrm{~h}$ $(\boldsymbol{\square})$, and $3 \mathrm{~h}(\boldsymbol{\Delta})$. The cells were washed and incubated with DME/ FBS and the cell numbers were determined at $24 \mathrm{~h}$ intervals. Control cells without $\mathrm{ET} 18-\mathrm{OCH}_{3}$ pretreatment were incubated with DME/ FBS $(\bigcirc)$ or DME/BSA $(\square) .(B)\left[{ }^{3} \mathrm{H}\right]$ Thymidine incorporation in cells treated with or without $\mathrm{ET} 18-\mathrm{OCH}_{3}(10 \mu \mathrm{g} / \mathrm{ml})$ for the indicated periods followed by stimulation with serum was determined. The results of both studies are the mean of six separate determinations.

creased their rate of proliferation relative to controls while incubation for $2 \mathrm{~h}$ or more completely inhibited cell proliferation. In cells preincubated with $\mathrm{ET} 18-\mathrm{OCH}_{3}$ for $3 \mathrm{~h}$ before incubation in DME/FBS for up to $4 \mathrm{~d}$, the proportion of cells excluding trypan blue dye ( $>90 \%$ ) was similar to that of controls, indicating that the viability of the cells had not been compromised. Preincubation of quiescent MCF-7 cells with ET18$\mathrm{OCH}_{3}$ followed by stimulation with serum also inhibited the incorporation of $\left[{ }^{3} \mathrm{H}\right]$ thymidine into the cells (Fig. $1 B$ ) indicating that progression of the cells into $\mathrm{S}$ phase had been inhibited. The quantities of ET18- $\mathrm{OCH}_{3}$ taken up by the cells after incubation for varying periods were determined with $\left[{ }^{3} \mathrm{H}\right]$
ET18-OCH $\mathrm{OCH}_{3}(5)$. After incubation for 1, 2, and $3 \mathrm{~h}$ with $10 \mu \mathrm{g} /$ ml ET18-OCH $\mathrm{OCH}_{3}$ the quantities of the ALP incorporated in the quiescent cells were $0.44,0.63$, and $0.74 \mu \mathrm{g} / 10^{6}$ cells, respectively. The above results suggested that the accumulated ET18$\mathrm{OCH}_{3}$ could be blocking the transduction of the growth signals in serum to the appropriate cellular proliferation machinery.

ET18- $\mathrm{OCH}_{3}$ inhibits the activation of $\mathrm{MAPK}$ in $\mathrm{MCF}-7$ cells. The activation of MAPK (ERK) is crucial for cell proliferation after stimulation by extracellular ligands, such as EGF, acting on receptor tyrosine kinases (17). To determine if the inhibitory locus of ET18- $\mathrm{OCH}_{3}$ was upstream or downstream of MAPK, cells were preincubated with or without ET18$\mathrm{OCH}_{3}(10 \mu \mathrm{g} / \mathrm{ml})$ for $3 \mathrm{~h}$, stimulated with EGF, and MAPK activity was measured in the cytosolic fractions. The results displayed in Fig. $2 A$ show that in control cells, MAPK activity peaked at $642 \mathrm{pmol} / \mathrm{min}$ per $\mathrm{mg}$ protein after $10 \mathrm{~min}$ stimulation whereas in cells preincubated with $\mathrm{ET} 18-\mathrm{OCH}_{3}$ a peak activity of $395 \mathrm{pmol} / \mathrm{min}$ per mg protein was observed after 5 min. At $10 \mathrm{~min}$, MAPK activity was 2.5 times higher in the controls compared with the cells preincubated with ET18$\mathrm{OCH}_{3}$. The in-gel MAPK assay revealed a similar inhibitory effect of ET18- $\mathrm{OCH}_{3}$ preincubation on MBP phosphorylation in response to EGF (Fig. 2 B). There was little or no differences between the controls and experimental cells after 2 and $4 \mathrm{~min}$ but at $10 \mathrm{~min}$, phosphorylation of MBP by $\mathrm{p} 42^{\mathrm{mapk}}$ and $\mathrm{p} 44^{\mathrm{mapk}}$ in the controls was still evident whereas that in the ET18- $\mathrm{OCH}_{3}$-treated cells had declined considerably. ET18$\mathrm{OCH}_{3}$ had a similar effect on MAPK activation in cells stimulated with serum (Fig. 2 A). Peak phosphorylation of MBP in control cell cytosol occurred 15 min after serum stimulation. In contrast, preincubation of the cells with $\mathrm{ET} 18-\mathrm{OCH}_{3}$ before serum stimulation yielded a peak activity at 10 min which was twofold lower than the peak activity in controls. 15 min after serum stimulation, MAPK activity in the ET18-OCH- -loaded cell cytosol was fourfold lower than the activity in controls. Thus, the effect of preincubating MCF-7 cells with ET18$\mathrm{OCH}_{3}$ under conditions that inhibit their proliferation was a decrease in both the intensity and duration of MAPK activation in response to serum or EGF. The observed inhibition of MAPK activation in cells preincubated with $\mathrm{ET} 18-\mathrm{OCH}_{3}$ is unlikely to be due to a direct inhibition of the enzyme activity by the compound because the activity of purified recombinant ERK2 and MAPK activity in the cytosolic fractions from stimulated cells were unaffected by the addition of up to $20 \mu \mathrm{g} / \mathrm{ml}$ exogenous ET18- $\mathrm{OCH}_{3}$ (data not shown).

ET18-OCH $\mathrm{H}_{3}$ decreases EGF-induced phosphorylation of $p 42^{\text {mapk }}$ and $p 44^{\text {mapk }}$. As phosphorylation of MAPK is required for its activation (28) we investigated the effect of ET18- $\mathrm{OCH}_{3}$ on this event. p42 ${ }^{\text {mapk }}$ and $\mathrm{p} 44^{\text {mapk }}$ were immunoprecipitated from $\left[{ }^{32} \mathrm{P}\right]$ orthophosphate-labeled cells incubated with or without ET18-OCH 3 and stimulated with EGF. Phosphorylation was assessed by autoradiography (Fig. $2 \mathrm{C}$ ). $4 \mathrm{~min}$ after EGF stimulation there was little difference in the phosphorylation of the MAPK immunoprecipitates from the control and experimental cells. However, while phosphorylation had not decreased after $10 \mathrm{~min}$ in MAPK immunoprecipitated from the control, this had declined significantly in MAPK immunoprecipitates from cells incubated with the ALP (3.2- and 3.7-fold decrease in $\mathrm{p} 42^{\mathrm{mapk}}$ and $\mathrm{p} 44^{\mathrm{mapk}}$ by densitometric analysis, respectively). Western blot analysis of parallel gels revealed no differences in MAPK protein content (data not 


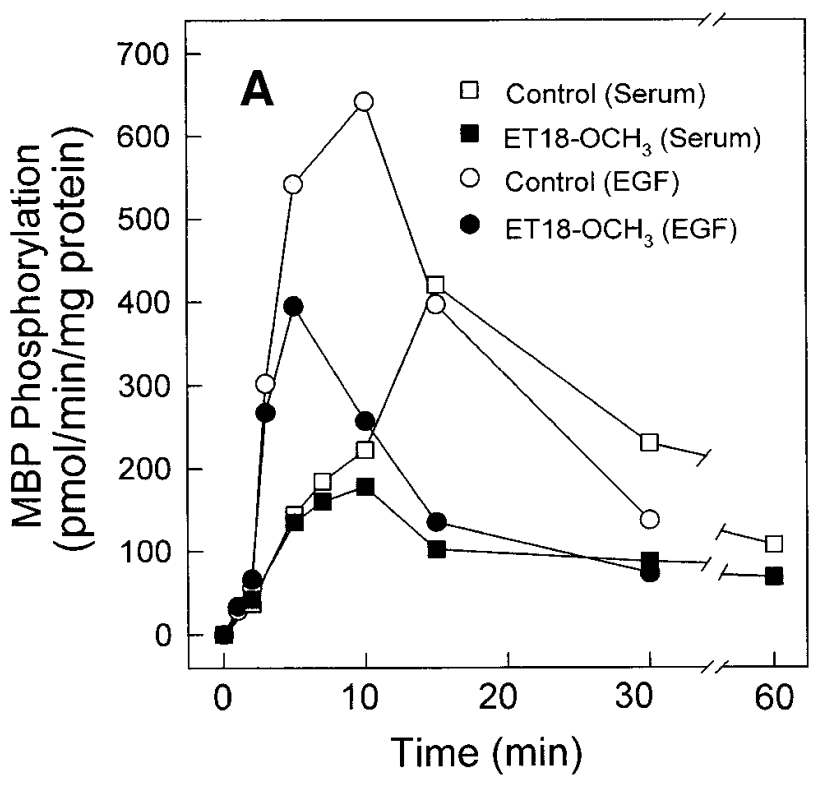

B

\begin{tabular}{|c|c|c|c|c|c|c|}
\hline ЕT18-ОСН3 & - & + & - & + & - & + \\
\hline EGF (min) & 0 & 0 & 4 & 4 & 10 & \\
\hline
\end{tabular}

C

\begin{tabular}{|c|c|c|c|c|c|c|c|}
\hline $\mathrm{ET}_{18-\mathrm{OCH}_{3}}$ & - & + & - & + & - & + & \\
\hline EGF (min) & 0 & $\mathbf{0}$ & 4 & 4 & 10 & 10 & $(-\mathbf{A b})$ \\
\hline $\begin{array}{l}\text { p44 } \\
\text { p42 } 42^{\text {mapk }}=\end{array}$ & & & $=$ & $=$ & $\underline{m}$ & $=$ & \\
\hline
\end{tabular}

Figure 2. Preincubation of MCF-7 cells with ET18-OCH $\mathrm{O}_{3}$ attenuates activation of MAPK in response to stimulation by EGF or serum. $(A)$ Quiescent cells were incubated without (open symbols) or with (closed symbols) ET18- $\mathrm{OCH}_{3}(10 \mu \mathrm{g} / \mathrm{ml})$ for $3 \mathrm{~h}$, washed and stimulated with EGF (circles) or DME/FBS (squares). MAPK activity was measured in cell cytosol as the phosphorylation of MBP. These results are from a single experiment that is representative of four separate experiments and the values are the mean of triplicate incubations. (B) Assessment of MAPK activity by the in-gel assay. Results from control and ET18-OCH${ }_{3}$-treated cells stimulated with EGF are displayed. The results are from a single experiment that is representative of two identical experiments. $(C)$ Assessement of $\mathrm{p} 42^{\mathrm{mapk}}$ and $\mathrm{p} 44^{\mathrm{mapk}}$ phosphorylation. Quiescent cells were prelabeled with [ $\left.{ }^{32} \mathrm{P}\right]$ orthophosphate, washed, and subsequently incubated with or without ET18- $\mathrm{OCH}_{3}(10 \mu \mathrm{g} / \mathrm{ml})$ for $3 \mathrm{~h}$ and stimulated with EGF. MAPK was immunoprecipitated from $750 \mu \mathrm{g}$ of cell cytosol protein with $3 \mu \mathrm{g}$ each of anti-ERK1 and -ERK2 Abs and resolved on $10 \%$ SDS-PAGE. MAPK phosphorylation was visualized by autoradiography. The results are from a single experiment that was repeated with three different cell preparations with similar results.

shown). These results suggest that the truncated activation observed in cytosol from cells preincubated with ET18- $\mathrm{OCH}_{3}$ was due to the decreased phosphorylation of MAPK, an indication that ET18- $\mathrm{OCH}_{3}$ probably affected an event upstream of MAPK that was critical to its sustained phosphorylation and activation. Experiments were initiated to investigate the effect of preincubating cells with $\mathrm{ET} 18-\mathrm{OCH}_{3}$ on the signaling events from EGF receptor to MAPK activation (17, 28-31).
Probe: $\alpha$ EGFr

\begin{tabular}{|c|cccccccc|}
\hline ET18-OCH3 & - & + & - & + & - & + & - & + \\
\hline EGF (min) & 0 & 0 & 2 & 2 & 5 & 5 & 10 & 10 \\
\hline
\end{tabular}

EGFr $=0 \mathrm{C}=\mathrm{E}$

\begin{tabular}{|c|cccccccc|}
\multicolumn{10}{|c|}{ Probe: $\alpha$ P-Tyr } \\
\hline ET18-OCH3 & - & - & - & - & + & + & + & + \\
\hline EGF (min) & 0 & 2 & 5 & 10 & 0 & 2 & 5 & 10 \\
\hline pY-EGFr & & & & & & & & \\
\hline
\end{tabular}

Figure 3. Preincubation with ET18- $\mathrm{OCH}_{3}$ does not affect the phosphorylation of EGF receptors in MCF-7 cells. Western blot analysis of immunoprecipitates of EGF receptor from cells incubated with or without ET18- $\mathrm{OCH}_{3}$ and subsequent simulation by EGF. Antibodies used for immunoblotting are indicated in the figures. The results are from a single experiment. Two independent experiments showed similar results.

ET18-OCH $\mathrm{H}_{3}$ does not affect activation of the EGF receptor. Studies on the binding and affinity of [125I]EGF to its receptors in cells incubated with or without $\mathrm{ET} 18-\mathrm{OCH}_{3}$ at 4 and $37^{\circ} \mathrm{C}$ revealed no significant differences in the quantity of EGF bound or affinity of EGF to the receptors (data not shown). Decreased internalization of EGF in cells preincubated with ET18- $\mathrm{OCH}_{3}$ relative to controls was observed at $37^{\circ} \mathrm{C}$, but this was only apparent after $20 \mathrm{~min}$ incubation with the ligand (data not shown). The effect of $\mathrm{ET} 18-\mathrm{OCH}_{3}$ on EGF receptor (EGFr) activation was assessed by monitoring the tyrosine phosphorylation of EGFr (32). Immunoblotting of the immunoprecipitated EGFr with anti-EGF ( $\alpha$ EGFr) Abs showed

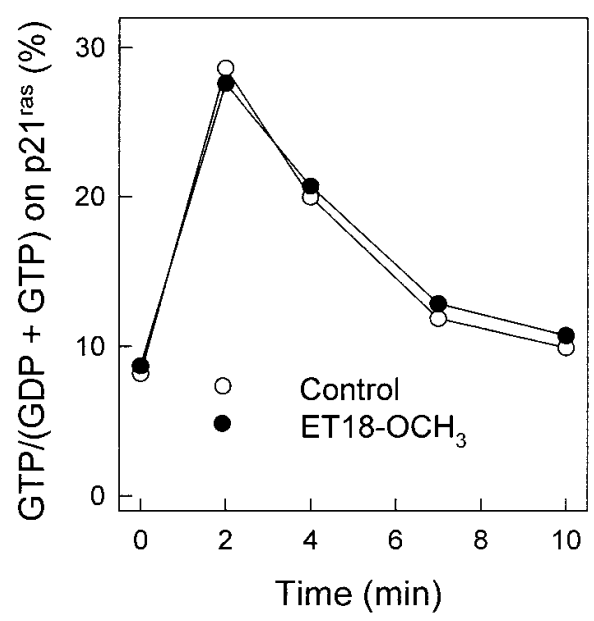

Figure 4. Pretreatment with ET18- $\mathrm{OCH}_{3}$ does not affect $\mathrm{p} 21^{\text {ras }}$ activation. $\mathrm{p} 21^{\text {ras }}$ was immunoprecipitated from cell lysates $(500 \mu \mathrm{g}$ protein) obtained from $\left[{ }^{32} \mathrm{P}\right]$ orthophosphate-labeled cells preincubated with or without ET18- $\mathrm{OCH}_{3}(10 \mu \mathrm{g} / \mathrm{ml})$ and subsequent stimulation with EGF. Guanine nucleotides were extracted from the immunoprecipitates and separated by TLC and the amount of associated radioactivity was visualized by autoradiography. Spots were scraped from the TLC plates and the radioactivity was quantitated. The results are from a single experiment that is representative of two identical experiments. 


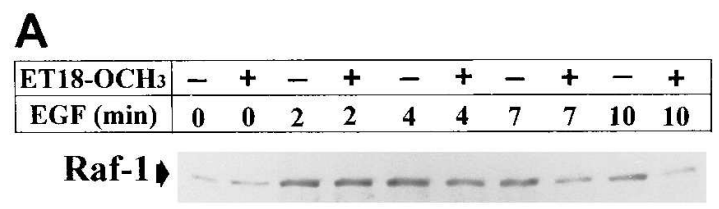

B

\begin{tabular}{|l|cccccccccc|}
\hline ET18-OCH3 & - & + & - & + & - & + & - & + & - & + \\
\hline Serum (min) & 0 & 0 & 5 & 5 & 10 & 10 & 15 & 15 & 30 & 30 \\
\hline
\end{tabular}

Raf-1

C

\begin{tabular}{|c|cccccccccc|}
\hline ET18-OCH & - & + & - & + & - & + & - & + & - & + \\
\hline EGF (min) & 0 & 0 & 2 & 2 & 4 & 4 & 7 & 7 & 10 & 10 \\
\hline
\end{tabular}

Raf-1 $\sim \ldots-\ldots$

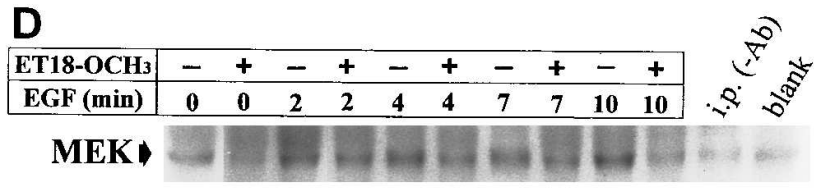

E

\begin{tabular}{|c|cccccccccc|}
\hline ET18-OCH3 & - & + & - & + & - & + & - & + & - & + \\
\hline EGF (min) & 0 & 0 & 2 & 2 & 4 & 4 & 7 & 7 & 10 & 10 \\
\hline H1 & & & & & &
\end{tabular}

Figure 5. Preincubaton of MCF-7 cells with ET18-OCH 3 attenuates Raf-1 activation. ( $A$ ) Effect of ET18- $\mathrm{OCH}_{3}$ on Raf-1 membrane association in EGF-stimulated cells. Quiescent cells were incubated with or without $\mathrm{ET} 18-\mathrm{OCH}_{3}(10 \mu \mathrm{g} / \mathrm{ml})$ for $3 \mathrm{~h}$ and stimulated with EGF. Membranes were prepared, solubilized and $40 \mu \mathrm{g}$ of protein were separated by $10 \%$ SDS-PAGE, transferred to nitrocellulose and immunoblotted with anti-Raf-1 Abs. The results are from a single experiment that is representative of those obtained with three different cell preparations. $(B)$ Effect of ET18- $\mathrm{OCH}_{3}$ on Raf-1 membrane association in serum-stimulated cells. Experiments and legends are similar to those in $A$ except stimulation was with DME/FBS. The results are from a single experiment that is representative of two identical experiments. $(C)$ Effect of ET18-OCH ${ }_{3}$ on Raf-1 content in MCF-7 cells. Experiments were conducted as described in $A$, but after stimulation, the cells were lysed in detergent containing buffer. Each lane was loaded with $10 \mu \mathrm{g}$ of total cell lysate protein. The legends are as described in $A$. The results are from a single experiment that is representative of two. $(D)$ Raf-1 kinase activity in ET18- $\mathrm{OCH}_{3}$-treated and control cells. Raf-1 was immunoprecipitated from membrane extracts of cells $\left(300 \mu \mathrm{g}\right.$ protein) treated with or without $\mathrm{ET} 18-\mathrm{OCH}_{3}$ $(10 \mu \mathrm{g} / \mathrm{ml})$ for $3 \mathrm{~h}$ followed by stimulation with EGF. The immunoprecipitates were washed and used in kinase assays to measure the phosphorylation of MEK-1 $(F L)$. Controls without Abs in Raf-1 immunoprecipitates and nonspecific phosphorylation of MEK-1 in assays with just buffer and $\left[\gamma^{32} \mathrm{P}\right] \mathrm{ATP}$ are also indicated. The results are from a single experiment. Two independent experiments showed similar results. $(E)$ Experiments were conducted as in $D$ but with histone $\mathrm{H} 1$ as substrate. Legends are the same as described in $D$. The results are from a single experiment that is representative of three independent experiments. that similar amounts of the receptor were present in cells incubated with or without $\mathrm{ET} 18-\mathrm{OCH}_{3}$ (Fig. 3). Immunoblotting with antiphosphotyrosine ( $\alpha \mathrm{P}-\mathrm{Tyr})$ Abs revealed that the extent and kinetics of EGFr phosphorylation were similar in both groups (Fig. 3). This was confirmed by densitometric analysis (data not shown).

ET18-OCH $\mathrm{OCH}_{3}$ does not affect the activation of $21^{\text {ras }}$. The activation of EGFr leads to the formation of a complex with Grb2/ mSos that leads to the activation of $\mathrm{p} 21^{\mathrm{ras}}(29)$ which in turn leads to Raf-1 activation to initiate the kinase cascade. Inhibition of $\mathrm{p} 21^{\text {ras }}$ activity could lead to decreased activation of MAPK. Fig. 4 shows that preincubation of the cells with ET18$\mathrm{OCH}_{3}$ had no effect on the activation of $\mathrm{p} 21^{\text {ras }}$ which peaked between 2 and $4 \mathrm{~min}$ and declined to resting values by $8 \mathrm{~min}$.

ET18-OCH $\mathrm{H}_{3}$ perturbs Raf-1 association with cell membranes. Activated p $21^{\text {ras }}$ mediates the translocation of Raf- 1 from the cytosol to the membrane where it is activated by undefined events $(17,30,31,33)$. To investigate the effect of ET18- $\mathrm{OCH}_{3}$ on Raf-1 activation, we examined its effect on the translocation of Raf from the cytosol to the membrane in control cells and those preincubated with $\mathrm{ET} 18-\mathrm{OCH}_{3}$. In cells stimulated with EGF (Fig. $5 \mathrm{~A}$ ), densitometric analysis of the blots revealed that the membrane-associated Raf- 1 in controls and cells preincubated with ET18- $\mathrm{OCH}_{3}$ increased similarly at 2 min while at 4 and $7 \mathrm{~min}, 1.8$ - and 3.4-fold more Raf-1, respectively, was associated with control membranes relative to membranes from ET18- $\mathrm{OCH}_{3}$-loaded cells. Results from serum-stimulated cells (Fig. 5 B) also revealed that Raf-1 association with membranes from cells preincubated with ET18$\mathrm{OCH}_{3}$ never attained the levels of the controls and decreased more rapidly. After 5 and 10 min the levels in membranes from ET18- $\mathrm{OCH}_{3}$-treated cells were 1.6- and 2.6-fold less than the levels in control membranes, respectively. Western blot analy-

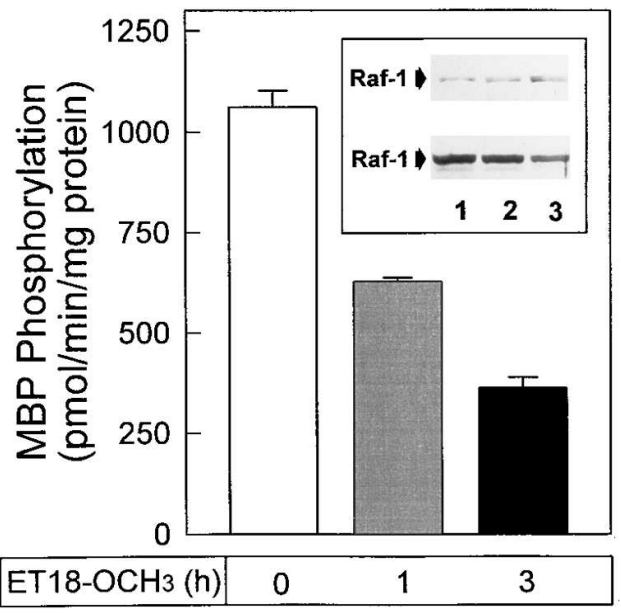

Figure 6. Effect of preincubation time with ET18-OCH $\mathrm{H}_{3}$ on Raf-1 membrane association and MAPK activity. Quiescent MCF-7 cells were incubated without (open bar; inset lane 1) or with ET18- $\mathrm{OCH}_{3}$ $(10 \mu \mathrm{g} / \mathrm{ml})$ for $1 \mathrm{~h}$ (grey bar; inset lane 2), or $3 \mathrm{~h}$ (black bar; inset lane 3). The cells were washed and stimulated with EGF for $7 \mathrm{~min}$. MAPK activity in the cytosolic fraction (bar graph) and Raf-1 association with the membrane (inset) were determined as described in Methods. Raf-1 associated with membranes from unstimulated and stimulated cells are shown in the upper and lower panels of the inset, respectively. Two independent experiments showed similar results. 
sis was performed on cell lysates to investigate whether the above differential association of Raf-1 with membranes was due to differences in the Raf- 1 content in cells treated with or without ET18-OCH . The results revealed that there were no differences in the Raf- 1 content between ET18-OCH- -treated and control cells (Fig. 5 C).

Preincubation of cells with ET18-OCH inhibits Raf-1 kinase activity. To investigate if the decreased Raf- 1 association caused by ET18- $\mathrm{OCH}_{3}$ preincubation translated into decreased Raf-1 kinase activity in the membrane, Raf-1 kinase activity was measured in Raf-1 immunoprecipitates from membranes of control and ET18- $\mathrm{OCH}_{3}$-loaded cells. The results clearly showed that there was greater phosphorylation of MEK-1 and histone $\mathrm{H} 1$ in assays with immunoprecipitates from control cells compared to those from cells preincubated with $\mathrm{ET} 18-\mathrm{OCH}_{3}$ (Fig. 5, $D$ and $E$ ), and the time course of the activity paralleled that of Raf-1 membrane association. The ratio of the increase in phosphorylation of the substrates over blanks in controls relative to $\mathrm{ET} 18-\mathrm{OCH}_{3}$-loaded cells as assessed densitometrically ranged from 1.5 at $2 \mathrm{~min}$ to 12 at 10 min for MEK-1 and 1.2 to 4.3 for histone $\mathrm{H} 1$ from 2 to $10 \mathrm{~min}$, respectively. Addition of $\mathrm{ET} 18-\mathrm{OCH}_{3}$ to the assays did not have any effect on the kinase activity of Raf-1 immunoprecipitates from EGF-stimulated and unstimulated cells (data not shown). Thus, ET18-OCH${ }_{3}$ has no direct effect on Raf-1 kinase activity.

Correlation between ET18-OCH 3 accumulation, Raf-1 membrane association and MAPK activation. As we observed a timedependent accumulation of $\mathrm{ET} 18-\mathrm{OCH}_{3}$ (see above), which could account for the differential effect on proliferation observed in Fig. 1, we investigated whether this could be correlated with differences in the extent of Raf- $1 /$ membrane association and MAPK activity. Quiescent MCF-7 cells were incubated with $\mathrm{ET} 18-\mathrm{OCH}_{3}$ for 0,1 , and $3 \mathrm{~h}$ before stimulation with EGF for $7 \mathrm{~min}$ and cell fractions processed for examination of Raf-1/ membrane association, and MAPK activity. The results (Fig. 6)

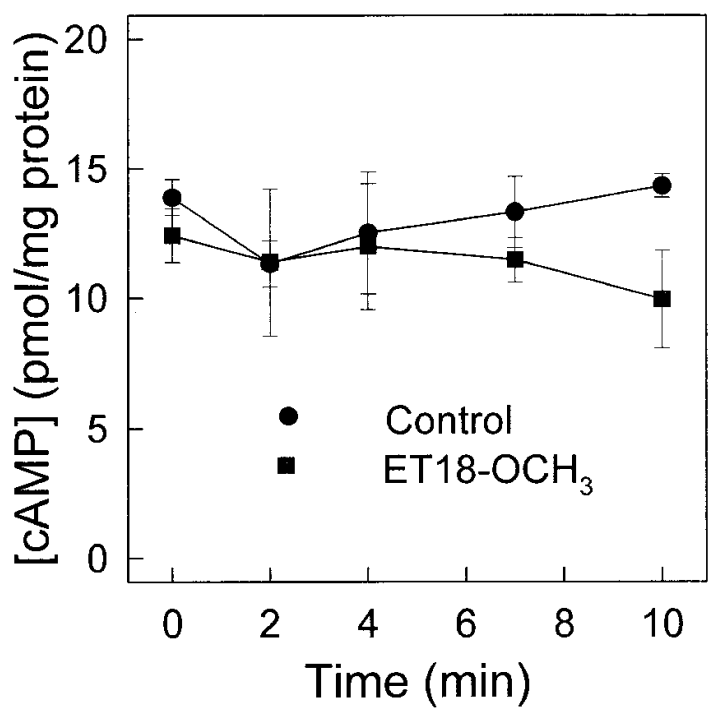

Figure 7. Effect of ET18- $\mathrm{OCH}_{3}$ on cellular cAMP content. cAMP levels in MCF-7 cells preincubated with or without $10 \mu \mathrm{g} / \mathrm{ml}$ ET18$\mathrm{OCH}_{3}$ for $3 \mathrm{~h}$ and stimulated with EGF $(10 \mathrm{ng} / \mathrm{ml})$ were determined as described in Methods. The results are the mean of two separate experiments conducted in triplicates.
Table I. Effect of Transient Stimulation of MCF-7 Cells on the Cytostatic Effects of ET18-OCH

\begin{tabular}{lcrr}
\hline & \multicolumn{3}{c}{ Cell cycle distribution $(\% \pm \mathrm{SD})$} \\
\cline { 2 - 4 } \multicolumn{1}{c}{ Treatment } & \multicolumn{1}{c}{$\mathrm{G}_{0} / \mathrm{G}_{1}$} & \multicolumn{1}{c}{$\mathrm{S}$} & \multicolumn{1}{c}{$\mathrm{G}_{2} / \mathrm{M}$} \\
\hline BSA & $81.5 \pm 3.1$ & $10.5 \pm 1.7$ & $8.0 \pm 1.8$ \\
ET18-OCH $/$ FBS & $81.7 \pm 2.8$ & $6.7 \pm 1.7$ & $11.5 \pm 1.3$ \\
FBS/BSA/FBS & $59.5 \pm 1.0$ & $24.2 \pm 1.0$ & $16.0 \pm 1.4$ \\
FBS/ET18-OCH $/$ /FBS & $66.0 \pm 2.9$ & $17.2 \pm 1.3$ & $16.2 \pm 2.2$
\end{tabular}

Quiescent MCF-7 cells were incubated with DME/FBS for $1 \mathrm{~h}$. The medium was removed, the cells were washed and incubated with ET18$\mathrm{OCH}_{3}(10 \mu \mathrm{g} / \mathrm{ml})$ in DME/BSA or DME/BSA alone for $3 \mathrm{~h}$. After removal of medium and washing, the cells were incubated in DME/FBS. Another group of cells were incubated with ET18-OCH $(10 \mu \mathrm{g} / \mathrm{ml})$ in DME/BSA for $3 \mathrm{~h}$ followed by washing and incubation with DME/FBS. All cells were harvested $25 \mathrm{~h}$ after initial treatment with DME/FBS and processed for flow cytometry analysis. The results are the mean of four independent experiments.

show that Raf- 1 association with the membrane decreased as a function of increasing incubation with ET18- $\mathrm{OCH}_{3}$ and that the order of decreasing MAPK activity correlated with decreased membrane-bound Raf-1 and increasing ET18- $\mathrm{OCH}_{3}$ accumulation.

Effect of ET18-OCH $\mathrm{OH}_{3}$ on cellular cAMP levels. Because PKA activation may lead to inhibition of Raf-1 activity (34), we determined the cAMP levels and PKA activity in ET18- $\mathrm{OCH}_{3}-$ pretreated and untreated MCF-7 cells to investigate whether the inhibitory effect of ET18- $\mathrm{OCH}_{3}$ was mediated via activation of PKA. ET18-OCH had no effect on unstimulated or EGF-stimulated cellular levels of cAMP (Fig. 7) or on PKA activity which remained unchanged from the basal level of $3.6 \pm 1.7 \mathrm{pmol} / \mathrm{min}$ per $\mathrm{mg}$ protein.

Effect of transient MCF-7 cell stimulation on the cytostatic effect of ET18-OCH . If the inhibition of the MAPK cascade by $\mathrm{ET} 18-\mathrm{OCH}_{3}$ contributes significantly to the antiproliferative effects of the compound as the above studies suggest, these effects should be minimized if the ALP is added subsequent to the transient activation of the cells. Quiescent MCF-7 cells were therefore incubated with DME/FBS for $1 \mathrm{~h}$ to transiently activate MAPK (Fig. 2). The cells were washed, and incubated with ET18-OCH 3 for $3 \mathrm{~h}$. At the end of this incubation the cells were washed and incubated with DME/FBS and subsequently processed for flow cytometric analysis. Table I shows that whereas preincubation with $\mathrm{ET} 18-\mathrm{OCH}_{3}$ before the addition of FBS completely inhibited cell cycle progression into $S$ phase, this inhibition was significantly blunted when the cells were transiently activated with FBS before addition of ET18- $\mathrm{OCH}_{3}$. The above results demonstrate that inhibition of the early signaling events by $\mathrm{ET} 18-\mathrm{OCH}_{3}$ contributes significantly to the antiproliferative action of the compound. However, the observation that there was a difference of $7 \%$ in the number of cells in $\mathrm{S}$ phase between control cells incubated without $\mathrm{ET} 18-\mathrm{OCH}_{3}(\mathrm{FBS} / \mathrm{BSA} / \mathrm{FBS})$ and those incubated with $\mathrm{ET} 18-\mathrm{OCH}_{3}$ after transient activation $\left(\mathrm{FBS} / \mathrm{ET} 18-\mathrm{OCH}_{3} /\right.$ FBS) suggests that the inhibition of cellular events by the ALP after the transient activation may also contribute to the inhibition of MCF-7 cell proliferation by $\mathrm{ET} 18-\mathrm{OCH}_{3}$. 


\section{Discussion}

The results of the current study demonstrate that in an ET18$\mathrm{OCH}_{3}$-sensitive cell line, uptake of the drug inhibits the sustained phosphorylation and activation of MAPK as a consequence of its effect on Raf-1. This is based on the following: [a] ET18- $\mathrm{OCH}_{3}$ had no effect on the binding of EGF to its receptors. Although EGFr internalization was inhibited as previously reported (8), this occurred after the decrease of MAPK activity to near-resting levels; $[b] \mathrm{ET} 18-\mathrm{OCH}_{3}$ did not affect the extent and kinetics of tyrosine phosphorylation of the EGFr, suggesting that ET18- $\mathrm{OCH}_{3}$ had no effect on EGFr kinase activity; [c] ET18- $\mathrm{OCH}_{3}$ did not affect the activation of p $21^{\text {ras }}$ in the cells; [d] Preincubation of cells with ET18- $\mathrm{OCH}_{3}$ did not reduce the Raf- 1 content of the cells but significantly decreased the duration of the association of Raf- 1 with the membrane within 4 min of stimulation. This reduced association correlated with a decrease in the membrane-associated Raf-1 kinase activity; $[e]$ Since $\mathrm{ET} 18-\mathrm{OCH}_{3}$ had no effect on the cellular cAMP levels and PKA activity, the inhibition of Raf-1 activity was not caused by a direct or indirect increase of PKA activity by ET18- $\mathrm{OCH}_{3}$; and $[f]$ The decrease in MAPK activity paralleled that of Raf-1 activity and resulted from decreased phosphorylation rather than a direct effect of ET18$\mathrm{OCH}_{3}$ on MAPK activity. The reduction in magnitude and duration of MAPK and the decreased association of Raf- 1 with membranes in MCF-7 cells preincubated with ET18- $\mathrm{OCH}_{3}$ after EGF or serum stimulation have also been observed in insulin-stimulated cells (Richard, C. and G. Arthur, personal observations).

The mechanism by which ET18- $\mathrm{OCH}_{3}$ interferes in the association of Raf- 1 with the membrane is not known. Since Ras activation, which localizes Raf- 1 to the membrane $(30,31)$, is unaffected by $\mathrm{ET} 18-\mathrm{OCH}_{3}$, it is not surprising that even though ET18- $\mathrm{OCH}_{3}$ was already present in the membrane before stimulation of the cells with growth factors, it was unable to prevent the initial increase in Raf-1 association with membranes. We believe the initial activation of MAPK after cell stimulation is due to the Ras-induced translocation and subsequent activation of Raf-1, but the presence of $\mathrm{ET} 18-\mathrm{OCH}_{3}$ in the membranes appears to activate or enhance a process that results in the dissociation of membrane-associated Raf- 1 much earlier than in the control cells. However, we cannot yet categorically rule out an effect of $\mathrm{ET} 18-\mathrm{OCH}_{3}$ on the translocation process. The enhanced dissociation of Raf-1 leads to the termination of the MAPK activity. Since growth inhibitory conditions with $\mathrm{ET} 18-\mathrm{OCH}_{3}$ used in the study did not completely block MAPK activation, we can surmise that the magnitude and duration of activation of the enzyme were insufficient for the phosphorylation and activation of downstream molecules to levels required to initiate proliferation. This interpretation is consistent with the postulation that the magnitude and duration of activation of MAPK is crucial in determining cellular responses to stimulation (17).

We do not know whether ET18- $\mathrm{OCH}_{3}$-induced inhibition of Raf-1 activation is due to a direct interaction of the compound with Raf-1, or whether this is achieved indirectly via its effects on unknown intermediary molecules required for the activation and/or attachment of Raf-1 to the membrane. It has been suggested that lipids may play a role in Raf-1 activation (35-37). Irrespective of the exact mode of action of ET18$\mathrm{OCH}_{3}$ on Raf-1, its ability to interfere in the activation of this key signaling molecule in a dose-dependent fashion should make it useful in assessing the effects of differential activation of the MAPK cascade on cellular responses.

The correlation between the accumulation of ET18- $\mathrm{OCH}_{3}$, the extent of growth inhibition, Raf-1/membrane association and MAPK activation suggests that the inhibition of the MAPK pathway by ET18- $\mathrm{OCH}_{3}$ is likely to contribute significantly to its antiproliferative effects. This view is supported by our recent studies demonstrating that $R$ and $S$ enantiomers of a double bond phosphonocholine ALP analog had differential effects on MCF-7 cell growth which correlated with their ability or inability to inhibit MAPK activation (Samadder, P., R. Bittman, H.-S. Byun, and G. Arthur, personal observations). The differential effects of the phosphonocholine enantiomers on cell proliferation also provides support for the widely held view that the inhibitory effects of ALPs are not due to nonspecific perturbation of membranes (reviewed in references 2, 3). The demonstration that inhibition of the early events in cell activation by ET18- $\mathrm{OCH}_{3}$ significantly contributes to its antiproliferative effects clearly implicates the inhibition of the MAPK cascade in the mechanism of action of the compound. However, as other signaling molecules such as PI-3K, PLC, and PKC that may be activated within this period could be inhibited by ALPs, this cautions against attributing the inhibition of growth by $\mathrm{ET} 18-\mathrm{OCH}_{3}$ solely to its ability to inhibit the MAPK cascade. An assessment of whether these molecules are inhibited under ET18- $\mathrm{OCH}_{3}$ preincubation conditions that inhibit Raf-1 activation and whether their activation is essential for growth will be required before such a conclusion can be made. There is evidence that inhibition of PKC by ALPs does not correlate with inhibition of cell growth $(2,11,12)$.

The localization of an inhibitory effect of $\mathrm{ET} 18-\mathrm{OCH}_{3}$ downstream of Ras, implies that $\mathrm{ET} 18-\mathrm{OCH}_{3}$ and related compounds should be effective against activating Ras mutations which have been observed in almost one-third of human cancers (38). Another implication of our study is that the apparent cell selective effects of ET18- $\mathrm{OCH}_{3}$ may be due to fundamental differences in the regulation of Raf-membrane associations between the ALP-sensitive and -insensitive cells or differences in the signal transduction pathways (Raf-dependent or -independent pathways) that mediate cell proliferation in different cell types. Future studies to resolve the basis of the selective effects should lead to the rational use of these compounds in cancer therapy.

\section{Acknowledgments}

We are very grateful to Drs. N. Ahn for purified recombinant ERK2, and Dr U. Rapp for anti Raf-1 antiserum (SP63).

This work was supported by a research grant from the National Cancer Institute of Canada (NCIC) with funds from the Canadian Cancer Society (to G. Arthur), a Research Scientist Award of NCIC (to D.W. Litchfield), and a Studentship Award from the Manitoba Health Research Council (to X. Zhou).

\section{References}

1. Berdel, W.E. 1991. Membrane-interactive lipids as experimental anticancer drugs. Br. J. Cancer. 64:208-211.

2. Lohmeyer, M., and R. Bittman. 1994. Antitumor ether lipids and alkylphosphocholines. Drugs Future. 19:1021-1037.

3. Houlihan, W.J., M. Lohmeyer, P. Workman, and S.H. Cheon. 1995. Phospholipid antitumor agents. Med. Res. Rev. 15:157-223.

4. Lu, X., and G. Arthur. 1992. Perturbations of cellular acylation processes 
by the synthetic alkyllysophospholipid 1-O-octadecyl-2- $O$-methylglycero3-phosphocholine do not correlate with inhibition of proliferation of MCF-7 and T84 cell lines. Cancer Res. 52:2806-2812.

5. Lu, X., and G. Arthur. 1992. The differential susceptibility of A427 and A549 cell lines to the growth-inhibitory effects of ET18- $\mathrm{OCH}_{3}$ does not correlate with the relative effects of the alkyl-lysophospholipid on the incorporation of fatty acids into cellular phospholipids. Cancer Res. 52:2813-2817.

6. Zhou, X., and G. Arthur. 1995. Effect of 1-O-octadecyl-2-O-methyl-glycero-phosphocholine on phosphatidylcholine and phosphatidylethanolamine synthesis in MCF-7 and A549 cells and its relationship to inhibition of cell proliferation. Eur. J. Biochem. 232:881-888.

7. Boggs, K.P., C.O. Rock, and S. Jackowski. 1995. Lysophosphatidylcholine and 1-O-octadecyl-2- $O$-methyl-rac-glycero-3-phosphocholine inhibit the CDP-choline pathway of phosphatidylcholine synthesis at the CTP:phosphocholine cytidylyltransferase step. J. Biol. Chem. 270:7757-7764.

8. Powis, G. 1991. Signalling targets for anticancer drug development. Trends Pharmacol. Sci. 12:188-194.

9. Helfman, D.M., K.C. Barnes, J.M. Kinkade, Jr., W.R. Vogler, M. Shoji, and J.F. Kuo. 1983. Phospholipid-sensitive $\mathrm{Ca}^{2+}$-dependent protein phosphorylation system in various types of leukemic cell lines HL60 and K562, and its inhibition by alkyl-lysophospholipid. Cancer Res. 43:2955-2961.

10. Heesben, E.C., L.F. Verdonck, S.W.G. Hermans, H.G. Van Heugten, G.E.J. Staal, and G. Rijksen. 1991. Alkyllysophospholipid ET-18-OCH $\mathrm{OCH}_{3}$ acts as an activator of protein kinase C in HL-60 cells. FEBS Lett. 290:231-234.

11. Salari, H., P. Dryden, R. Davenport, S. Howard, K. Jones, and R. Bittman. 1992. Inhibition of protein kinase C by ether-linked lipids is not correlated with their antineoplastic activity on WEH1-3B and R6X-B15 cells. Biochim. Biophys. Acta. 1134:81-88.

12. Berkovic, D., K. Berkovic, E.A. Fleer, H. Eibl, and C. Unger. 1994. Inhibition of calcium-dependent protein kinase $\mathrm{C}$ by hexadecylphosphocholine and 1-O-octadecyl-2- $O$-methyl-rac-glycero-3-phophocholine do not correlate with the inhibition of proliferation of HL60 and K562 cell lines. Eur. J. Cancer. 30A:509-515.

13. Seewald, M.J., R.A. Olsen, I. Sehgal, D.C. Melder, E.J. Modest, and G. Powis. 1990. Inhibition of growth factor-dependent inositol phosphate $\mathrm{Ca}^{2+}$ signaling by antitumor ether lipid analogues. Cancer Res. 50:4458-4463.

14. Powis, G., M.J. Seewald, C. Gratas, D. Melder, J. Riebow, and E.J. Modest. 1992. Selective inhibition of phosphatidylinositol phospholipase C by cytotoxic ether lipid analogues. Cancer Res. 52:2835-2840.

15. Berggren, M.I., A. Gallegos, L.A. Dressler, E.J. Modest, and G. Powis. 1993. Inhibition of the signalling enzyme phosphatidylinositol-3-kinase by antitumor ether lipid analogues. Cancer Res. 53:4297-4302.

16. Parker, P.J., and M.D. Waterfield. 1992. Phosphatidylinositol 3-kinase: a novel effector. Cell Growth \& Differ. 3:747-752.

17. Marshall, C.J. 1995. Specificity of receptor tyrosine kinase signaling: transient versus sustained extracellular signal-regulated kinase activation. Cell. 80:179-185.

18. Inglese, J., W.J. Koch, K. Touhara, and R.J. Lefkowtiz. 1995. G $\mathrm{B}_{\beta \gamma}$ interactions with $\mathrm{PH}$ domains and Ras-MAPK signalling pathways. Trends Biochem. Sci. 20:151-156.

19. Ashagbley, A., P. Samadder, R. Bittman, R.K. Erukulla, H.-S. Bynn, and G. Arthur. 1996. Synthesis of ether-linked analogues of lysophosphatidate and their effect on the proliferation of human epithelial cells in vitro. Anticancer Res. In press.

20. Ahn, N.G., J.E. Weiel, C.P. Chan, and E.G. Krebs. 1990. Identification of multiple epidermal growth factor-stimulated protein serine/threonine ki- nases from Swiss 3T3 cells. J. Biol. Chem. 265:11487-11494.

21. Bogoyevitch, M.A., A. Clerk, and P.H. Sugden. 1995. Activation of the mitogen-activated protein kinase cascade by pertussis toxin-sensitive and -insensitive pathways in cultured ventricular cardiomyocytes. Biochem. J. 309:437-443.

22. Corbin, J.D., and E.M. Reimann. 1974. Assay of cyclic AMP-dependen protein kinases. Methods Enzymol. 38:287-290.

23. Li, B.-Q., D. Kaplan, H. Kung, and T. Kamata. 1992. Nerve growth factor stimulation of the Ras-guanine nucleotide exchange factor and GAP activities. Science (Wash. DC). 256:1456-1459.

24. Wartmann, M., and R.J. Davis. 1994. The native structure of the activated Raf protein kinase is a membrane-bound multi-subunit complex. J. Biol. Chem. 269:6695-6701.

25. Kharbanda, S., A. Saleem, Y. Emoto, R. Stone, U. Rapp, and D. Kufe. 1994. Activation of Raf-1 and mitogen-activated protein kinases during monocytic differentiation of human myeloid leukemia cells. J. Biol. Chem. 269:872878

26. Piazza, G.A., J.L. Ritter, and C.A. Baracka. 1995. Lysophosphatidic acid induction of transforming growth factors $\alpha$ and $\beta$ : modulation of proliferation and differentiation in cultured human keratinocytes and mouse skin. Exp. Cell Res. 216:51-64.

27. Edelmann, H.M.L., C. Kuhne, C. Petritsch and L.M. Ballou. 1996. Cell cycle regulation of p70 S6 kinase and p42/p44 mitogen-activated protein kinases in Swiss mouse 3T3 fibroblasts. J. Biol. Chem. 271:963-971.

28. Anderson, N.G., J.L. Maller, N.K. Tonks, and T.W. Sturgill. 1990. Requirement for integration of signals from two distinct phosphorylation pathways for activation of MAP kinase. Nature (Lond.). 343:651-653.

29. Egan, S.E., B.W. Giddings, M.W. Brooks, L. Buday, A.M. Sizeland, and R.A. Weinberg. 1993. Association of Sos Ras exchange protein with Grb2 is implicated in tyrosine kinase signal transduction and transformation. Nature (Lond.). 363:45-51.

30. Stokoe, D., S.G. Macdonald, K. Cadwallader, M. Symons, and J.F. Hancock. 1994. Activation of raf as a result of recruitment to the plasma membrane. Science (Wash. DC). 264:1463-1467.

31. Leevers, S.J., H.F. Paterson, and C.J. Marshall. 1994. Requirement for ras in raf activation is overcome by targeting raf to the plasma membrane. $\mathrm{Na}$ ture (Lond.). 369:411-414.

32. Panayotou, G., and M.D. Waterfield. 1993. The assembly of signalling complexes by receptor tyrosine kinases. Bioessays. 15:171-177.

33. Marais, R., Y. Light, H.F. Paterson, and C.J. Marshall. 1995. Ras recruits Raf- 1 to the plasma membrane for activation by tyrosine phosphorylation. EMBO J. 14:3136-3145.

34. Cook, S.J., and F. McCormic. 1993. Inhibition of cAMP of ras-dependent activation of raf. Science (Wash. DC). 262:1069-1072.

35. Dent, P., D.B. Reardon, D.K. Morrison, and T.W. Sturgill. 1995. Regulation of Raf-1 and Raf-1 mutants by Ras-dependent and Ras-independent mechanisms in vitro. Mol. Cell. Biol. 15:4125-4135.

36. Cai, H., P. Erhardt, J. Troppmair, M.T. Diaz-Meco, G. Sithanandam, U.R. Rapp, J. Moscat, and G.M. Cooper. 1993. Hydrolysis of phosphatidylcholine couples Ras to activation of Raf protein kinase during mitogenic signal transduction. Mol. Cell. Biol. 13:7645-7651.

37. Ghosh, S., J.C. Strum, V.A. Sciorra, L. Daniel, and R.M. Bell. 1996. Raf-1 kinase possesses distinct binding domains for phosphatidylserine and phosphatidic acid. J. Biol. Chem. 271:8472-8480.

38. Lowy, D.R., and B.M. Willumsen. 1993. Function and regulation of ras. Annu. Rev. Biochem. 62:851-891. 